\title{
Cognitive functioning and behaviour of epileptic children in parents' assessment
}

\section{Funkcionowanie poznawcze i zachowanie dzieci chorych na padaczkę w opinii ich rodziców}

\author{
Dorota Talarska', Barbara Steinborn², Michał Michalak ${ }^{3}$ \\ 1Department of Health Promotion, Karol Marcinkowski Poznan University of Medical Sciences, Poznan \\ 2Department of Developmental Neurology, Karol Marcinkowski Poznan University of Medical Sciences, Poznań \\ ${ }^{3}$ Department of Computer Science, Karol Marcinkowski Poznan University of Medical Sciences, Poznań
}

Neurologia i Neurochirurgia Polska 2011; 45, 5: 474-479

\begin{abstract}
Background and purpose: Cognitive functioning and behaviour of chronically ill children are affected by many factors, including anxiety due to hospitalization, persistent symptoms of sickness and adverse side effects of medications. The aim of this work was to seek out parents' opinion concerning cognitive functioning and behaviour of children with epilepsy.

Material and methods: The study comprised 156 children with epilepsy aged 7-18 and treated in the Department of Developmental Neurology at Karol Marcinkowski Poznan University of Medical Sciences and in an outpatient clinic. The research tool used was the questionnaire Quality of Life in Childhood Epilepsy (QOLCE) completed by parents. Assessment of cognitive functioning and behaviour was based on the analysis of the areas $\mathrm{V}$ (cognitive processes) and VII (behaviour).

Results: Parents assessed children's functioning in the areas of cognitive processes and behaviour at a similar level 55 points. In the area of cognitive processes, concentration while performing some tasks and reading was assessed as the worst. A significant difference in caregivers' assessment was found according to age, frequency of seizures and duration of disease. In the area analysing the child's behaviour, parents indicated getting angry easily and not being upset by other people's opinions. The display of aggression towards others got the lowest number of comments.
\end{abstract}

Conclusions: The children's functioning was assessed by parents as rather poor in both analysed areas. Parents of children treated with polytherapy noticed more difficulties in cog-

\section{Streszczenie}

Wstęp i cel pracy: Na funkcjonowanie poznawcze oraz zachowanie dzieci przewlekle chorych wpływa wiele elementów, m.in. niepokój spowodowany hospitalizacją, utrzymujące się objawy chorobowe oraz działania niepożądane leków. Celem pracy było poznanie opinii rodziców na temat zachowania i funkcjonowania poznawczego dzieci chorych na padaczkę.

Materiał i metody: Badaniem objęto grupę 156 dzieci w wieku 7-18 lat chorych na padaczkę, leczonych w Klinice Neurologii Wieku Rozwojowego Uniwersytetu Medycznego im. Karola Marcinkowskiego w Poznaniu i w przyklinicznej poradni. Narzędziem badawczym był kwestionariusz Quality of Life in Childhood Epilepsy (QOLCE), wypełniany przez rodziców. Funkcjonowanie poznawcze dzieci i zachowanie oceniono na podstawie analizy obszaru V (procesy poznawcze) i VII (zachowanie).

Wyniki: Rodzice ocenili funkcjonowanie dzieci w obszarach procesy poznawcze i zachowanie na podobnym poziomie, tj. ok. 55 punktów. W obszarze dotyczącym procesów poznawczych opiekunowie najgorzej ocenili koncentrację dzieci podczas wykonywania jakiegoś zadania oraz czytania. Wykazano różnicę istotną statystycznie w ocenie opiekunów dotyczącej funkcjonowania poznawczego dzieci, w zależności od ich wieku, częstości napadów oraz czasu trwania choroby. W obszarze analizującym zachowanie dziecka wśród najczęściej występujących nieprawidłowości rodzice wskazali łatwość złoszczenia się oraz nieprzejmowanie się opinią innych osób. Najmniej uwag dotyczyło natomiast przejawiania agresji wobec innych.

Correspondence address: Dorota Talarska, Katedra Profilaktyki Zdrowotnej, ul. Smoluchowskiego 11,60-179 Poznań, mail: pati.talarska@neostrada.pl Received: 13.07.2010; accepted: 24.05.2011 
nitive functioning and behaviour than parents of children treated with one medication.

Key words: children, epilepsy, cognitive function, behaviour.

\section{Introduction}

Mental development of school-aged children with epilepsy is in $80 \%$ within the norm or slight retardation range [1]. These children can learn in primary schools but $30 \%$ have partial deficiency in cognitive function and sight and hearing disorders. Significant importance in ensuing disorders of cognitive processes is given to the aetiological factors of epilepsy, types of seizures and their frequency [2]. The age of the child at the onset of first seizures is also decisive in the development of cognitive functions.

Beside fear and anxiety, a negative emotional reaction to the disease is anger, manifested by the child's passive and active resistance. It may be intensified by different types of restrictions imposed on a child [3]. Mild depression and insecurity additionally trigger behavioural disorders.

Behavioural disorders are defined as deviation from the norm, understood as moral rules, customs and traditions accepted in a given society. They are triggered by environmental and genetic factors as well as the child's individual features [4].

These factors can obstruct relations with others and the learning process, making it necessary to repeat classes or give up education, which in turn may lead to contact with pathological groups and establishment of antisocial behaviour $[4,5]$. Chronically sick adolescents are additionally burdened with disrupted education and relations with peers due to periodic hospitalization, persistent symptoms or adverse side-effects of medication.

In children and adolescents with epilepsy, the greatest difficulties are caused by the persistent seizures and adverse side effects of medication [6-8].

The aim of the work was to seek out parents' opinion regarding behaviour and cognitive functioning of children with epilepsy.

\section{Material and methods}

Data of 164 children with epilepsy aged 7-18 were reviewed. All of them were treated in the Department
Wnioski: $\mathrm{W}$ obu analizowanych obszarach funkcjonowanie dzieci zostało stosunkowo nisko ocenione przez rodziców. Rodzice dzieci, u których zastosowano politerapię, dostrzegali więcej trudności w funkcjonowaniu poznawczym i zachowaniu, niż rodzice dzieci leczonych jednym lekiem.

Słowa kluczowe: dzieci, padaczka, funkcje poznawcze, zachowanie.

of Developmental Neurology at Karol Marcinkowski Poznan University of Medical Sciences and in an outpatient clinic.

Among the studied children, 116 (70.7\%) patients were treated with one antiepileptic drug (AED), and $40(24.4 \%)$ received polytherapy consisting of two or three AEDs. Due to absence of seizures the medication was discontinued in 8 (4.9\%) patients. These children were excluded from the study. Finally, the study group consisted of 156 respondents.

Criteria adopted for participating in the studies were as follows: (1) monotherapy or polytherapy, (2) absence of other coexisting sicknesses, (3) IQ within normal scope, and (4) parents' and child's consent for participation in the studies.

The research tool used was the Quality of Life in Childhood Epilepsy (QOLCE) questionnaire [9]. The QOLCE questionnaire was filled in by parents. It enabled the analysis of 7 areas (16 fields): child's physical activity, physical and mental state, cognitive functions, social activity, behaviour, general health and general assessment of the quality of life. In each part the child could score the maximum of 100 points. The assessment of children's cognitive functioning was based on the analysis of the areas V (cognitive processes) and VII (behaviour).

Additionally, another questionnaire was prepared which enabled us to gather clinical information (i.e. the frequency and type of seizures, duration of illness and medication). The influence of medication on children's functioning is discussed in a separate article [8]. Before commencing the studies, the cultural adaptation of QOLCE was done. The validity of the Polish version of the questionnaire was verified by the Cronbach $\alpha$ coefficient of $0.93[7,10]$, whereas Mathiak et al. had an $\alpha$ coefficient of 0.97 [11].

For the statistical analysis, the analysis of variance was applied and the data verification was based on the Kruskal-Wallis and Fisher tests. 


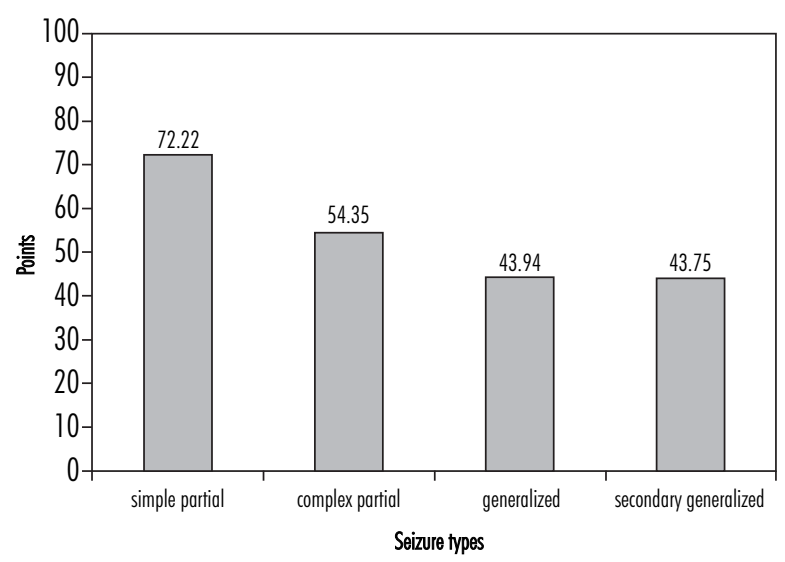

Fig. 1. Remembering information by children and the seizure type (parents' assessment)

\section{Results}

There were $79(50.6 \%)$ girls and 77 (49.4\%) boys among the studied children. For statistical purposes they were divided into three age groups representing the Polish education levels: 7-12 years, 13-15 and 16-18. In the first age group, there were $84(53.85 \%)$ children, in the second 45 (28.84\%), and the third group (children over 16) was less numerous $(27,17.31 \%)$.

At the time of the study, 9 (5.8\%) patients had seizures every day; 43 (27.6\%) had seizures 1 to 4 times a month; $32(20.5 \%)$ experienced seizures 1-2 times every 6 months; and $72(46.1 \%)$ had a seizure once a year. Simple partial seizures occurred in 14 (9\%) subjects, complex partial seizures in 28 (17.9\%), primary generalized seizures in $77(49.4 \%)$, and secondary generalized seizures in 37 (23.7\%) children.

Based on the answers given by parents in the separate areas of the whole questionnaire, the functioning of children was estimated at the average level from 50.29 to 75.83 points.

In the area of cognitive functions, the questions were concerned with the parents' observation regarding memorizing, concentration and the child's understanding of single and complex instructions.

The average result for this part of the questionnaire was 55.25 points. The caregivers estimated the children's concentration during performing tasks (mean 44.5 points) and reading (mean 46.6 points) as the worst. The child's reaction to orders given by a caregiver was also estimated negatively (45.51 points).

According to parents, memorizing information from previously read text imposed problems (mean 50.00 points) as well as formulating conclusions and solving problem tasks (mean 52.71 points). A smaller number of abnormalities was observed in the area of memorizing names (mean 75.30 points), understanding single orders/instructions (mean 72.50 points) and holding a conversation (mean 71.72 points).

In the area concerning behaviour, parents estimated the children's functioning at 55.09 points. The lowest score and, accordingly, the most problems, were reported regarding easy outburst of anger (mean 29.18 points) and not getting upset by other people's opinion (mean 47.71 points).

An additional difficulty was the necessity of more caregivers' supervision of the child (mean 44.95 points). However, such conduct as hitting and attacking people (mean 67.75 points) or swearing in public (mean 65.13 points) was observed rarely. Among questions analysed in this area, obedience was assessed as relatively high (mean 65.85 points).

Parents' estimations regarding cognitive functioning of children and their behaviour were analysed with such variables as age, sex, duration of the sickness, types of seizures and frequency of epileptic seizures.

A statistically significant difference was demonstrated in the parents' estimation regarding cognitive functioning of the child according to their age ( $p=0.0476)$, frequency of seizures $(p=0.0028)$ and duration of the illness $(p=0.0205)$. Regarding the type of seizure, differences in parents' answers were only demonstrated in the statements regarding the child's difficulties in remembering information from a text read a few hours or days earlier (Fig. 1) and in failing to carry out previously planned activities. Children with primary and secondary generalized seizures got lower scores. Parents' estimation regarding the second analysed area, children's behaviour, showed a significant statistical difference only with reference to the variable sex of the child ( $p=0.0493$ ). According to parents' assessment, the girls behaved better.

The biggest differences were demonstrated in the answers regarding swearing in public and not getting upset by other people's opinion about them.

Because of substantial differences in administered medication in the therapy, the impact of pharmacotherapy on the cognitive processes and the behaviour was analysed in two groups: monotherapy and polytherapy (Fig. 2).

It was found that parents of children treated with two or more drugs more often noticed difficulties in performing single $(p=0.0345)$ and complex orders $(p=0.0349)$, whereas in the area assessing behaviour they more often emphasized the necessity of more supervision $(p=0.0311)$. 


\section{Discussion}

Development of psycho-social features in a child depends on inborn and acquired personality traits, type and course of the disease, conditions and method of treatment and applied educational methods [3]. Cognitive functioning reflects the functioning of the central nervous system (CNS). Mojs [12] proposed the division of cognitive functions into global (intelligence) and selective, which include such disorders as dyslexia, dysgraphia and dyscalculia. The level of intelligence for $80 \%$ of school-aged children is within the norm or in slight impairment. However, more often than in other healthy groups, selected disorders of cognitive functions and emotions are present $[1,7,13,14]$. Their occurrence has a negative impact on children's learning abilities $[2,12]$.

In the QOLCE questionnaire, parents' estimation of children cognitive functioning was mostly concerned with memorizing, attention and carrying out orders by a child. Differences in the answers given by the respondents were analysed according to the age of the child, frequency and type of seizures and duration of illness. Children from the 7-13 age group with seizures occurring more than once a month and children with the duration of illness up to 5 years obtained lower scores. Children from the oldest group with seizures once a year and duration of illness 5-10 years scored the best in parents' estimation as having the fewest difficulties in cognitive functioning.

A significant factor causing disorders in cognitive functioning is the age at onset of epilepsy. First seizures occurring in early childhood may cause problems with working memory, ability to learn and visual-motor integration $[12,13,15]$. In our study group, the most difficulties in remembering, attention and understanding of the orders were observed among children from the youngest group, which may be the result of little school adaptation and the need for more assistance with homework. Also in this group the majority of children had the onset of seizures before they were 5 .

The age of the child with illness duration of 5-10 years may have influenced the parents' estimation. They were usually children more independent in preparation for school, who spent more time with their peers; therefore the caregivers' estimation was more concerned with the child's functioning at home and less with school performance.

An analysis of the influence of seizure type on the children's cognitive functioning demonstrated that parents better estimated these functions in children with simple seizures than primary and secondary generalized seizures. General tonic-clonic seizures, according to other authors' opinion,

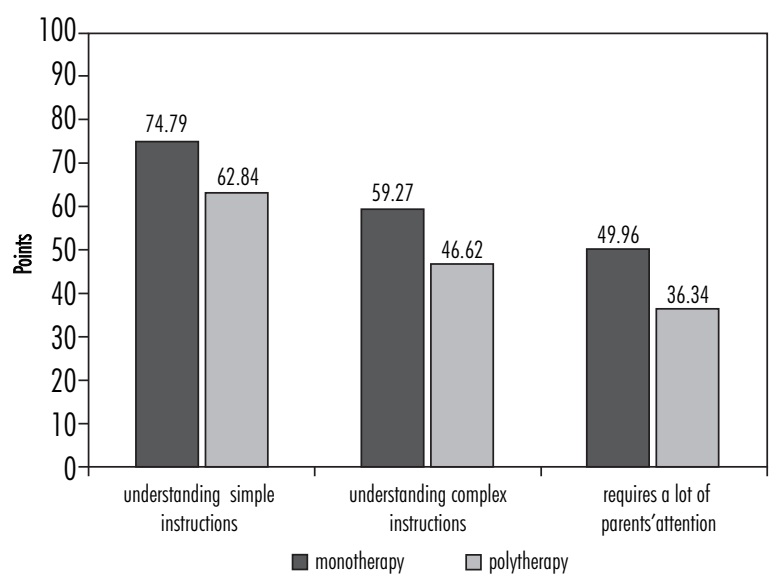

Fig. 2. The impact of mono- and polytherapy on selected components of cognitive processes and behaviour

more often lead to disorders of cognitive functions than simple and complex partial seizures $[12,16,17]$. Children with partial seizures usually do not have more difficulties than their healthy peers.

Among disorders diagnosed in this group, the most common is the lower gathering of information in longterm memory and problems with recalling this information [12]. Also in some epileptic syndromes, there were observed disorders of cognitive functions. In a group of children with juvenile myoclonic epilepsy (JME), disorders connected with the front lobe in abstract thinking and in flexibility of thinking were present [18]. In the studies conducted by Wendorff et al. [19] and Reijs [20] in children with so-called Rolandic epilepsy, the intelligence quotient did not differ from the level of the healthy peers. However, deficits in cognitive function in auditory memory and logical thinking were reported.

The process of cognitive functioning is influenced not only by the damage to the CNS but also by the frequency of seizures [12,21]. Epilepsy is a disease characterised by a varied course, but most often (75-80\%) they are cases with less frequent seizures and responsive to pharmacological treatment [22]. Mental powers and cognitive functions in this group usually do not differ from the average $[1,22]$. More abnormalities in cognitive functions can be observed in patients with drug-resistant epilepsy and with intensified side effects $[8,12,13,23]$. In our study, children with drug-resistant epilepsy also scored lower. Marcenkowski et al. [23] observed the influence of AED on memory and concentration, mostly when the dose was rapidly increased.

New AED in the mentioned study had more beneficial influence on the cognitive functions than the con- 
ventional ones. In their own research, parents brought up problems with memorizing school material and information given by the teacher or from previously read books or newspapers. Another problem was the attention deficit while performing a certain task or while reading. These problems were more often present in children treated with polytherapy. Similar observations were made by McEwan et al. [24], Owczarek [22] and Sabaz [9]. It has been commonly assumed that high doses of AED and polytherapy impair attention, motor speed and memory [13].

Indirect information about the proper functioning of cognitive processes is provided by children's academic achievement. Problems with learning of different intensity are indicated by $30-70 \%$ of children with epilepsy and they usually arise from not understanding mathematical formulae and deficient graphomotor skills $[7,25,26]$. Difficulties frequently reported by children and their parents are as follows [25]: remembering previously read text (37\%), in performing mathematical tasks (25\%), in writing $(23 \%)$ and in reading texts (15\%). Similar problems were reported in parents' own study. Difficulties in reading are more common among children with complex partial seizures than in children with generalized seizures. They are disorders of the phonological process and are intensified in children with the epileptic focus located in the frontal lobe [18]. According to Fastenau [27], children's learning problems stem from the model presented by them: 1 - neuropsychological functioning that probably is a consequence of structural and electrophysiological disorders; 2 - seizure features; there was no information which features exactly (there are no explicit conclusions in the literature), about seizure type, frequency, age of the first seizure; 3 - demographic variables; 4 - psychosocial.

Disorders in efficiency of the process of perception, attention, and reduction in memory capacity may be triggered by emotional factors [3]. Emotional and personality disorders are present in approximately $20-50 \%$ of epileptic patients, regardless of the location of the disorder in the CNS [12].

Emotional disorders can be of primary character, so the aetiological factor may have the same cause that triggered epilepsy. Other factors are the damage to the CNS in the course of epilepsy and pharmacotherapy [13,16,21]. Secondary disorders are influenced by the relations in the child's environment, the most common form being lack of control and aggressive behaviour [14,28].

Aggressive behaviour is rarely observed in patients with epilepsy (less than 5\% of cases). If there are such behaviours, they are usually the result of a given situa- tion. They are also observed among patients with the damage to the CNS and cognitive functions. In the study conducted by Hoare and Kerley [26] with the Rutter Parent and Teacher Questionnaire, teachers and parents pointed out the most common neurotic disorders among children. They included loneliness, irritability, fear and anxiety, fidgeting and poor concentration. However, antisocial behaviours such as playing truant, theft or aggression occurred rarely.

There were no differences observed between the behaviour of girls and boys. Similarly, in the parents' study, behaviour disorders were concerned with the situations of getting angry very fast and not getting upset by other people's remarks, while aggressive behaviours were observed rarely. Contrary to the authors mentioned earlier [26], respondents in their own study noticed a difference in the behaviour according to the gender of the child; the girls scored better.

Abnormalities in behaviour were reported in more than half of the children, which gives a higher percentage than described (30-50\%) in the works of other authors $[12,26]$. In their own study parents reported the fewest problems in the behaviour of teenagers over 16 years of age with a short duration of illness (up to 5 years) and generalized seizures. Frequent behaviour disorders are observed in patients with complex partial seizures and the epileptic focus located in the temporal lobe [14]. It is believed that hippocampal sclerosis is a significant factor causing aggressive behaviour in the course of temporal lobe epilepsy.

Aggression and hyperactivity are often mentioned as adverse side effects of medication $[8,16,29]$. Also bad relations with the caregiver can cause the build-up of aggression and distancing from peers $[4,28]$. The lack of stability in relationships may strengthen the defiance of moral and social norms, which, in turn, can lead to educational and academic difficulties [4].

Cognitive processes and behaviour can be disturbed in the course of epilepsy due to modified factors (dose, kind of medication, frequency of seizures) and factors that cannot be modified such as the age at onset of seizures. Because these processes can significantly influence social relations, ability to learn, and consequently, professional activity, they are considered as a measure in the quality of life estimation. Psychological tests which enable such estimation and the monitoring of cognitive functions and emotions should complement the diagnostics in epilepsy. For a more comprehensive view, parents and patients' observations should be taken into consideration. 


\section{Conclusions}

1. In parents' opinion the greatest difficulties in cognitive functioning stem from poor concentration and short-term memory.

2. In the area of behaviour, parents indicated most of all easily getting angry.

3. Children treated with two or more medications were given a worse estimation by their parents in both analysed areas than those treated with one AED.

\section{Disclosure}

The authors report no conflict of interest.

\section{References}

1. Baker G.A., Jacoby A., Buck D., et al. Quality of life of people with epilepsy: a European study. Epilepsia 1997; 38 (suppl): 353-362.

2. Aldenkamp A.P. Effect of seizures and epileptiform discharges on cognitive function. Epilepsia 1997; 38 (suppl): 52-55.

3. Pecyna M.B. Dziecko i jego choroba. Wyd. Akademickie Żak, Warszawa 2000, pp. 28-75.

4. Kurpas D., Kaczmarek M., Steciwko A. Zaburzenia zachowania u dzieci i młodzieży. In: Pierogowicz I., Steciwko A. [eds.] Dziecko i jego środowisko. Promocja zdrowia i profilaktyka chorób w pediatrii. Wyd. Continuo, Wrocław 2007, pp. 125-134.

5. Nowicka A. Psychospołeczne funkcjonowanie dzieci chorych w świetle wyników badań. In: Nowicka A. Psychospołeczna integracja dzieci przewlekle chorych w szkole podstawowej. Wyd. Impuls, Kraków 2001, pp. 103-146.

6. Artemowicz B., Otapowicz D., Sobaniec W., et al. Wyniki badania jakości życia dzieci z padaczką. Neurol Dziec 2003; 12: 21-27.

7. Talarska D. Funkcjonowanie psychospołeczne dzieci i młodzieży z napadami kontrolowanymi i padaczką oporną na leki - analiza porównawcza. Epileptologia 2006; 14: 35-43.

8. Talarska D., Steinborn B. Wpływ wybranych leków przeciwpadaczkowych na jakość życia dzieci z padaczką. Neurol Dziec 2009; 36: $25-30$

9. Sabaz M., Cairns D.R., Lawson J.A., et al. Validation of a new quality of life measure for children with epilepsy. Epilepsia 2000; 41: 765-774

10. Talarska D. Jakość życia dzieci z padaczką w oparciu o kwestionariusz Quality of Life in Childhood Epilepsy. Pol Med Rodz 2004; 6: 42-44.

11. Mathiak K.A., Karzeł K., Mathiak K., et al. Kwestionariusz jakości życia w padaczce dziecięcej - polska adaptacja kwestionariusza. Neurol Neurochir Pol 2007; 41: 203-214.

12. Mojs E., Gajewska E., Głowacka M.D., et al. Występowanie zaburzeń poznawczych i emocji w padaczce i ich implikacje dla terapii. AAMS 2007; 53: 82-87.

13. Pavone P., Bianchini R., Trifiletti R.R., et al. Neuropsychological assessment in children with absence epilepsy. Neurology 2001; 56: 1047-1051.
14. Mojs E., Gajewska E. Stygmatyzacja dzieci i młodzieży z padaczką. Pieleg Pol 2007; 1: 29-33.

15. Majkowski J. Standardy diagnostyki i leczenia chorych z padaczką w Polsce. Raport Komisji Polskiego Towarzystwa Epileptologii. Epileptologia 2002; 10: 109-130.

16. Halczuk I. Wpływ nowych leków przeciwpadaczkowych na funkcje poznawcze. Farm Psych Neurol 2005; 4: 363-379.

17. Mandelbaum D.E., Burack G.D., Bhise V.V. Impact of antiepileptic drugs on cognition, behavior, and motor skills in children with new-onset, idiopathic epilepsy. Epilepsy Behav 2009; 16: 341-344.

18. Wendorff J. Zaburzenia funkcji poznawczych u dzieci z padaczką. Forum Neurol 2004; 1: 39-41.

19. Wendorff J. Zaburzenia poznawcze w padaczce rolandycznejkorelacje z zapisem elektroencefalograficznym. Przegl Lek 2006; 63 (suppl 1): 14-17.

20. Reijs R.R., de la Parra N.M., van Mil G.M., et al. Motor function in children with cryptogenic localization related epilepsy. Seizure 2010; 19: 467-469.

21. Motamedi G., Meador K. Epilepsy and cognition. Epilepsy Behav 2003; 4: S25-S38.

22. Owczarek K. Psychospołeczne aspekty padaczki. Epileptologia 1998; 2: 123-137.

23. Marcenkowski I., Błażewicz J., Bikszajewa J., et al. Wpływ terapii przeciwpadaczkowej na poziom zdolności poznawczych i funkcjonowanie chorych na padaczkę. Epileptologia 2003; 11: 17-26.

24. McEwan M.J, Espie C.A, Metcalfe J. Quality of life and psychosocial development in adolescents with epilepsy: a qualitative investigation using focus group methods. Seizure 2004; 13: 15-31.

25. Kłos E., Zielińska A. Funkcjonowanie młodzieży chorej na padaczkę w środowisku szkolnym. Pieleg XXI Wieku 2006; 3: 139-141.

26. Hoare P., Kerley S. Psychosocial adjustment of children with chronic epilepsy and their families. Dev Med Child Neurol 1991; 23: 201-215.

27. Fastenau P.S., Shen J., Dunn D.W., et al. Neuropsychological predictors of academic underachievement in pediatric epilepsy: moderating roles of demographic, seizure, and psychosocial variables. Epilepsia 2004; 45: 1261-1272.

28. Oostrom K.J., van Teeseling H., Smeets-Schouten A., et al. Three to four years after diagnosis: cognition and behaviour in children with "epilepsy only". A prospective, controlled study. Brain 2005; 128: 1546-1555.

29. Zaccara G., Gangemi P.F., Cincotta M. Central nervous system adverse effects of new aniepileptic drugs. A meta-analysis of placebo-controlled studies. Seizure 2008; 17: 405-421. 